\title{
THE CONSTRUCTION OF RELIGIOSITY ROLE IN CAUSALITY RELATIONSHIP WITH CONSUMER BEHAVIOR INTENTION
}

\author{
Daru Asih 1), Ridho Bramulya Ikhsan 2), Nurul Komara Fajrin ${ }^{3)}$, Fadhila Dhia Malihah ${ }^{4)}$ \\ ${ }^{1,3,4)}$ Universitas Mercu Buana, Jakarta, Indonesia \\ ${ }^{2}$ Universitas Bina Nusantara, Jakarta, Indonesia \\ Corresponding author: daru.asih1303@gmail.com
}

\begin{abstract}
This study is intended to examine the role of religiosity in the causal relationship between the use of Instagram social media and consumers' behavioral intentions towards culinary products, whether the role of the construct of religiosity in the relationship mediates or moderates. In addition, the purpose of this study was to examine the effect of using advertising through social media, in this case, Instagram, on the behavioral intentions of consumers on SME culinary products. The survey was conducted on 200 respondents using Instagram using the purposive sampling technique. Data analysis was performed using Structural Equation Modeling with the Smart PLS program.
\end{abstract}

Keywords: Religiosity, Social Media, Advertising, Consumer Behavior Intention

\section{Introduction}

In 2020, almost the entire world will be exposed to Covid-19. Covid-19 is a disease caused by infection with the new coronavirus or SARS-CoV-2. The World Health Organization (2020) explains that Coronaviruses infect the respiratory system. The increase in status from epidemic to pandemic officially announced by the World Health Organization on March 11, 2020 (WHO, 2020) became an extraordinary event that had never been predicted before. Determination of a pandemic itself considers a contagious disease and spreads to many regions or countries. The COVID-19 pandemic has had economic, social, and political implications for almost all countries worldwide. At the global economic level, the Covid-19 pandemic has had a significant impact on the economy of nation-states and the existence of SMEs (Pakpahan, 2020).

Small and Medium Enterprises were most negatively affected during the Covid-19 pandemic. The Covid19 pandemic is predicted to kill SMEs (Carruthers, 2020). The SME sector is considered to have the highest vulnerability to this pandemic because, generally, SMEs earn from daily trade turnover (Shofiana, 2020). The physical distancing and PSBB (Large-Scale Social Restrictions) policies have directly impacted the survival of cooperatives and SMEs. The problems faced are lack of capital, declining sales, and hampered distribution (Masduki, 2020).

Based on the results of a survey conducted by the Central Statistics Agency (BPS), $82.85 \%$ of entrepreneurs experienced a decrease in income due to the Covid-19 pandemic. Small and medium enterprises experienced the most decline, which reached $84 \%$ (Katadata.co.id). A survey conducted by the Association of Business Development Services Indonesia (ABDSI) on 6,405 respondents who are MSME business actors spread throughout Indonesia, with the following results.

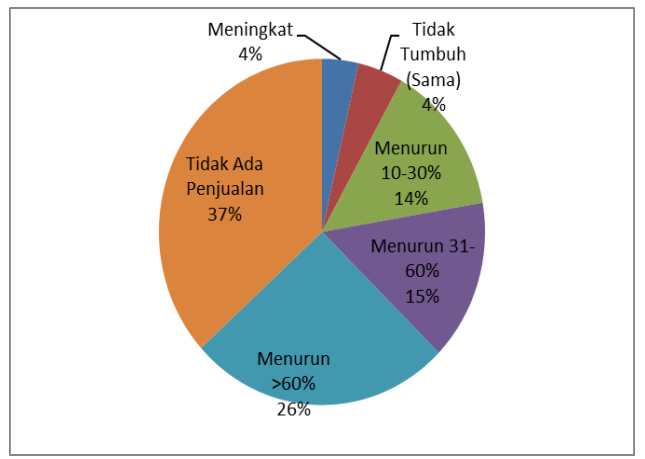

Source: Katadata.co.id

Figure 1. Decrease in SME Sales Impact of the Covid-19 Pandemic

Based on Figure 1., one of the impacts of Covid-19, the decline in sales that was almost felt by all SMEs. A total of $36.7 \%$ of respondents admitted that there were no sales. Furthermore, as many as $26 \%$ of respondents realized a decrease of more than $60 \%$. On the other hand, only $4 \%$ were in the same or nongrowing position and the same amount of $4 \%$, which experienced an increase in sales.

During a pandemic like this, SMEs must innovate more to manage their marketing strategies. One strategy to increase sales during this pandemic is to do online marketing because the increase in shopping through online media or online continues to experience a pretty drastic increase (Kompas.com, 2020). The 
increase in online shopping is very high, reaching $400 \%$ quoted from the words of the Director-General of Post and Information Technology (PPI) of the Ministry of Communication and Information, Ahmad M. Ramli, in a meeting with the Tourism Recovery Committee at Commission X DPR on July 7, 2020, "In the pandemic era and entering the new normal In this case, telecommunications is oxygen for all of us, you may even say that online shops during this pandemic have increased by 400 percent" (CNN Indonesia, 2020).

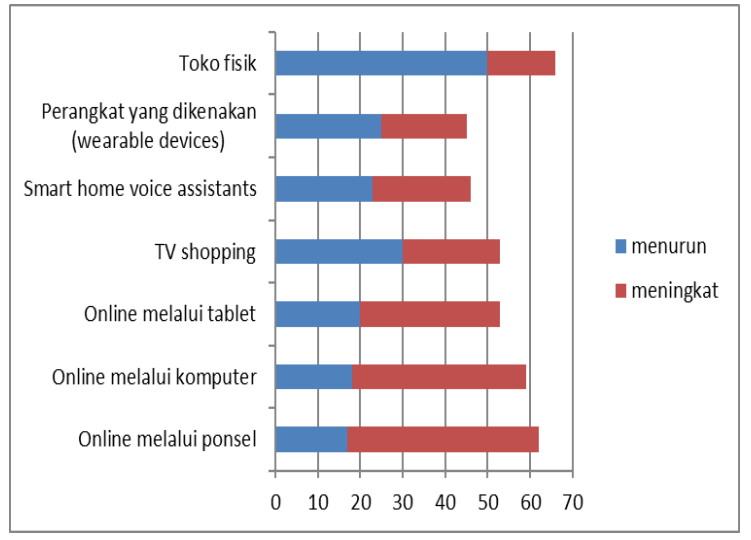

Source: Databoks.com, 2020

Figure 2. Data on Decrease and Increase in Spending during the Covid-19 Pandemic

Based on Fig 2. above, after the Covid-19 outbreak, shopping via mobile or digital shows an increasing trend. Most people transact using mobile phones online, and its growth reached $45 \%$. On the other hand, shopping directly at physical stores is reduced by $50 \%$ and supported by other online shopping backed by devices such as online via computers, tablets, TV shopping, Smarthome voice assistants, and wearable devices.

The increase in online shopping through mobile phones is the most that reach more than $60 \%$. This can be used for business people by marketing through social media to increase their sales, one of which is Instagram. According to data quoted by (Patardo 2020) in Tek. Id shows that the increase in Instagram usage has reached $40 \%$ during the pandemic. Currently, the use of Instagram is not only focused on individual use but has also expanded for other purposes, including business interests. In business, Instagram is used as a means to be able to introduce and promote a product and brand to potential consumers so that they are interested in wanting to buy or using the products offered. This is considering the current trend of people who like Instagram social media to fulfill their information needs for something, including food and drink or culinary (Kompasiana.com, 2019).

Instagram is considered to have advantages as a promotional tool for a product because it is cheaper to produce, has a broad reach, is easy to update, is easy for people to access, and has many conveniences when we use Instagram as a promotional medium (Herna, Hisnawati, Hidayarturahmi, \& Putri, 2019). These advantages underlie companies and business units of various scales using Instagram as a promotional medium

The scope of this research is still related to the construct of religiosity. In contrast to previous research, in which, in this case, religiosity is associated with interest in choosing a Sharia hotel, in this research, the construct of religiosity is associated with the intention of consumer behavior on SME halal culinary products. The study aimed to examine the effect of advertising on Instagram social media on the behavioral intentions of consumers towards halal culinary by placing the construct of religiosity as a moderating variable and as a mediating variable. This research is still very relevant to examining the Proposing Research Team (TPP) and the Partner Research Team (TPM).

Previous research related to consumer behavioral intentions has also been carried out by Kurniaputri et al. (2020), Larasati et al. (2020), Rois (2016), Kristiadi \& Hartiyah (2017), Rahman et al. (2015), Ashraf et al. (2017) which discusses the intention of consumer behavior. However, there has not been much previous research that examines the purpose of consumer behavior during the covid-19 pandemic. This research is urgent because the culinary industry, especially in the SME sector, has experienced a very sharp decline due to the Covid19 pandemic, which has lasted for almost a year. From the originality aspect, this research is still very original because the phenomenon is new, and the Covid19 pandemic emergency is ongoing. In addition, the discussion of the construct of religiosity in the context of consumer behavior is still a hot topic and a matter of debate. The conceptualization of religiosity and measurement instruments still needs to be developed. Contribution of research on practical aspects, the results of this study can provide additional information for the culinary industry and SMEs in carrying out their marketing strategies. The theoretical contribution of this research is to provide new insights regarding the role of the construct of religiosity in the causal relationship between the related variables. The most prominent contribution is the answer to research questions regarding the role of religiosity in the relationship, whether to mediate or moderate. 


\section{Literature Review \\ Media Social}

Maoyan (Indika \& Jovita, 2017) said that social media is a technology network used to create news through internet users and communicate and disseminate information, while social media marketing is a type of internet marketing model to achieve marketing goals by participating in the scope of media networks. Social. Meanwhile, according to Stockdale, Ahmed, and Scheepers (Purwarna, Rahmi, \& Aditya, 2017), social media is a group of internet-based applications that create the ideological and technological foundations of Web 2.0 that allows the creation and exchange of user-generated content. Based on the statement above, the definition of social media or social media is an online communication tool via the internet between people with one another without any boundaries between users to find the information they are looking for or share data between fellow social media users.

\section{Instagram}

Understanding Instagram according to (Atmoko 2012), Instagram is a photo-sharing application that allows users to take photos, apply digital filters, and share them to various social networking services, including Instagram's own. Meanwhile, according to (Nisrina 2015), Instagram is an application used to share photos and videos. Instagram itself is still a part of Facebook, which allows our Facebook friends to follow our Instagram account. The increasing popularity of Instagram as an application used to share photos makes many users who go into online business also promote their products through Instagram. Based on the explanation above, it can be concluded that Instagram is a social media application for communicating and interacting. Its principal function is to share photos and videos with fellow Instagram social media users whose distribution is vast and unlimited.

\section{Advertising Through Social Media (Instagram)}

Advertising through Instagram is the right thing to do at this time because Instagram is considered to have advantages as a promotional tool for a product because it is cheaper to produce, has a broad reach, is easy to update, easy for people to access, and many conveniences when we use it. Instagram as a promotional medium (Herna, Hisnawati, Hidayarturahmi, \& Putri, 2019). Advertising through social media Instagram, according to (Putri, 2017) is an activity to market a product or service that is marketed through internet technology using the Instagram social media platform.

\section{Consumer Behavior Intention}

Consumer behavior intentions can be interpreted as consumers who have not made an action to purchase a product or service at present and are likely to purchase in the future. Behavioral intention to buy or purchase intention arises after receiving a stimulus from the product he sees, and from there arises an interest to buy to have it (Kotler \& Armstrong, 2015). Meanwhile, according to (Hasan 2013), purchase intention is the tendency of consumers to buy a brand or take action to relate to a purchase which is measured by the level of possibility of consumers making a purchase. According to (Sciffman \& Kanuk, 2015), purchase intention is a psychological force that exists within the individual, impacting an action. Purchase intention is considered a measurement of the possibility of consumers buying a particular product where the high intention effects the potential of a large enough purchase decision.

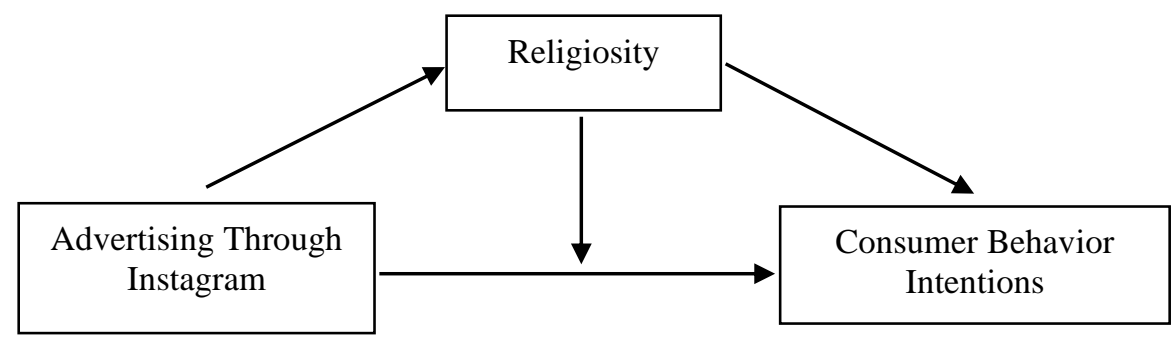

Figure 3. Research Framework

\section{The Effect of Advertising Through Instagram on Consumer Behavior Intentions}

Previous research, according to (Lininati 2018); (Indika \& Jovita, 2017), (Admiral 2018), and (Teo, Leng, \& Phua, 2019), stated that advertising through Instagram social media influences purchase intention. Other studies related to consumer behavioral intentions have been carried out by Kurniaputri et al. (2020), Larasati et al. (2020), Rois (2016), Kristiadi \& Hartiyah (2017), Rahman et al. (2015), Ashraf et al. (2017). Based on this, it can be formulated into a hypothesis as follows:

H1: Advertising through Instagram has a positive effect on consumer behavioral intentions.

H2: Advertising through Instagram has a positive impact on religiosity

H3: Religiosity has a positive impact on consumer behavioral intentions 
H4: The impact of advertising through Instagram on consumer behavioral intentions is moderated by religiosity.

\section{Research Methods}

The research design used in this study is a causal design. According to Neuman (2013), causal design is a causal relationship. The research was conducted to determine the effect of one or more independent variables on the dependent variable. The independent variable is the variable that affects or causes the change or emergence of the dependent variable. This causal research aims to examine the effect of advertising through social media on purchase intentions by taking into account several variables, namely the religiosity variable. The approach used in this research is quantitative. The population in this study are people who live in Jakarta, Banten, and surrounding areas. Sampling carried out by this researcher is through a non-probability sampling technique because the magnitude of the probability of an element being selected as a subject is unknown. The sampling method was carried out by the convenience sampling method. According to Neuman (2014), convenience sampling is taking respondents as samples based on chance; that is, anyone who coincidentally meets a researcher can be used as a sample if the person they meet is suitable as a data source with the main criteria being that person is a consumer or customer. The example in this study was 200 respondents based on Hair et al. (2010) theory, namely the indicator multiplied by $5-10$.

The statement indicators in this study were 40 items. So 40 items multiplied by five is 200 respondents. The data obtained in this study were obtained from filling out the questionnaire. A questionnaire is a data collection technique done by giving a set of questions or written statements to respondents to answer. Questionnaires can be closed or open questions or comments and can be given to respondents directly or sent by post or internet (Neuman, 2014). The questionnaire used is a closed questionnaire where the researcher previously determined alternative answers (Noor, 2016). Data analysis was performed using Structural Equation Modeling - PLS.

\section{Result and Discussion}

This report used Structural Equation Modelling - PLS to analyze the data. Our findings revealed that the relationship between the influence of advertising through Instagram on consumer behavioral intentions, a pvalue of 0.010 ( $\mathrm{p}$-value <0.05) was obtained, with a t-statistic of 2.588 (t-statistic > 1.96). This can be interpreted that the $\mathrm{H} 1$ hypothesis is accepted, which means that advertising through Instagram has a positive and significant effect on consumer behavioral intentions on Instagram online media service users in searching for SME products in Indonesia.

Furthermore, based on the analysis of the relationship between Instagram ads and religiosity, a p-value of 0.028 (p-value <0.05) was obtained, with a t-statistic of 2.210 ( $\mathrm{t}$-statistic > 1.96). This indicates that hypothesis $\mathrm{H} 2$ is accepted, meaning that advertising through Instagram has a positive and significant effect on religiosity on Instagram online media users searching for MSME products in Indonesia.

In the H3 hypothesis analysis, the results of the study of the relationship between religiosity and consumer behavioral intentions obtained a p-value of 0.000 (p-value $<0.05$ ), with a t-statistic of 0.994 ( $t$ statistic > 1.96). This indicates that the $\mathrm{H} 3$ hypothesis is accepted, which means that religiosity has a positive and significant effect on Consumer Behaviour Intentions on Instagram online service users in searching for MSME products in Indonesia.

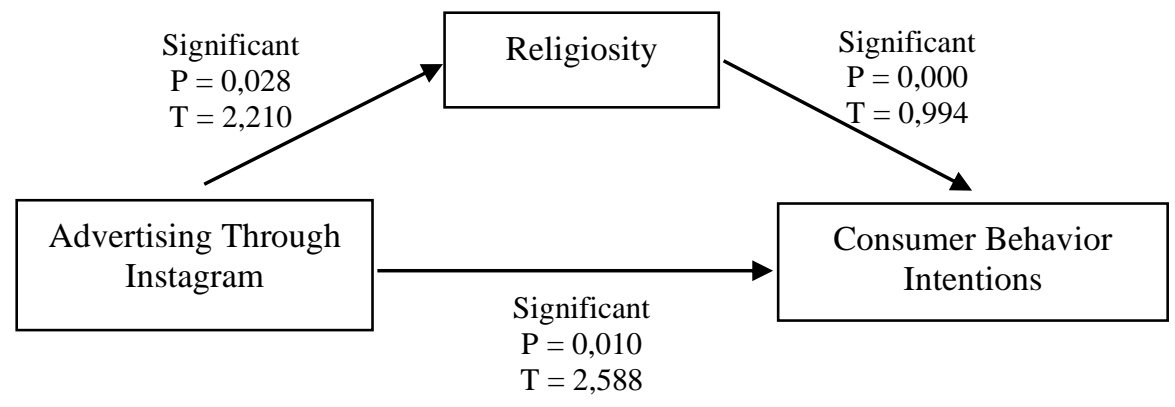

Figure 4. The Relationship of Advertising through Instagram with Consumer Behaviour Intentions through Mediation of Religiosity

Figure 4 shows the results of the value relationship (Advertising through Instagram with Religiosity (IMI$>\mathrm{RG})$ ) with t-statistics (2.210) and p values (0.028), indicating that the relationship between the two variables is significant, and the importance of a (relationship of knowledge sharing with innovation ( RG->IKK)) with significant t-statistics (0.994) and $\mathrm{p}$ values (0.000). While the value of $\mathrm{c}$ (the relationship between social capital variables and innovation (IMI > IKK)) with at-statistics value (2.588) and p values (0.010) is significant. The relationship of social capital (A), knowledge sharing (B), and innovation (C) are substantial, and the value of coefficient $\mathrm{c}(0.994)$ is more than the coefficient $\mathrm{b}(2.588)$. So it is said that it is not 
mediation, then the hypothesis (H7) is rejected. Religiosity cannot mediate advertisements through Instagram on consumer behavioral intentions on Instagram users in searching for MHM products in Indonesia.

The results of this study have theoretical implications and practical implications. On the theoretical implications, this study adds research literature on consumer behavior seen through the variables of religiosity and the advertising media used. IG advertising media makes it easy for users to find the desired product. The level of religiosity has a positive influence on the attention of consumer behavior in looking for products advertised in online media.

While the theoretical implications raise consumer behavior's attention towards a product offered many things that must be considered. Complete information about the halalness of a product is a consideration for consumers in choosing and buying a product. In contrast, IG media facilitates MSME products to share detailed information about the products being sold.

\section{Conclusion}

In summary, based on the results of the analysis and discussion of the research results, it can be concluded as follows; Advertising through Instagram has been proven to positively and significantly affect consumer behavioral intentions. This means that the better and more apparent the advertisements on Instagram media, the better consumers' behavioral purposes. Instagram is an online medium for all ages with clear information and a platform that is easy to understand and of outstanding quality. It positively responds to users of the MSME products they want to find; Advertising through Instagram has been proven to positively and significantly affect religiosity. This means that the better information about a halal product in advertising media, the better the value of religiosity. This means that advertisements made on Instagram online media must be careful and detailed regarding halal information. This is an essential factor for online media users in making product decisions; Religiosity has been proven to have a positive and significant effect on consumer behavior intention. This means that the better and stronger the religious value of a person, the more careful they will be in choosing the products offered on IG advertising media. The higher the attention of consumer actors on the halalness of the product when the level of religiosity is high; Religiosity is a positive and insignificant mediation of the relationship between advertising through Instagram and consumer behavior intention. This means that the better a person's religiosity, the lower his attention on consumer behavior. Being very careful in choosing the products offered makes the feeling of wanting to buy products online less.

To maintain and increase the attention of consumer behavior of product users in Indonesia, the following suggestions can be followed; The content on Instagram can be enjoyed by everyone. Therefore, there is a need to increase more attention to how IG displays different characteristics in their advertising or marketing strategy; Advertising on IG online media should invite users to feel the content of spiritual activities. MSME products can be advertised, inviting consumers to participate in religious activities; The religiosity variable used as mediation in the study did not produce significant results, so that in the following research, it needs to be re-examined. Subsequent research Religiosity needs to be tested how its role becomes moderated.

\section{References}

Adnan, A., Idrees, M., \& Farooq, M. (2018). Relationship Between Marketing Mix Strategies And Fashion Consumer's Purchase Intention. International Journal Of Scientific \& Engineering Research, Vol.9, No.12.

Aji, B. P., \& Zuhroh, S. (2016). Pengaruh Promosi Di Media Sosial Dan Word Of Mouth Terhadap Keputusan Pembelian. Jurnal Komunikasi, Vol.10, No.2, 145-160.

Amalia, N. (2019). Pengaruh Citra Merek, Harga Dan Kualitas Produk Terhadap Keputusan Pembelian (Studi Kasus Pada Konsumen Mie Endess Di Bangkalan). Jurnal Studi Manajemen Dan Bisnis, Vol.6, No.2.

Atmoko, B. D. (2012). Instagram Handbook Tips Fotografi Ponse. Jakarta: Media Kita.

BBC News Indonesia. (2020, April). Virus Corona: Gelombang PHK Di Tengah Pandemi Covid-19 Diperkirakan Mencapai Puncak Bulan Juni. Retrieved Oktober 12, 2020, From Https://Www.Bbc.Com/Indonesia/Indonesia-52218475

CNN Indonesia. (2020, Juli 7). Belanja Online Naik 400 Persen Saat Musim Corona. Retrieved September 19, 2020, From Https://Www.Cnnindonesia.Com/Ekonomi/20200707172450-92-521925/Belanja-OnlineNaik-400-Persen-Saat-Musim-Corona

Databoks.Com. (2020, Agustus 26). Konsumen Beralih Berbelanja Secara Digital Saat Pandemi. Retrieved September 19, 2020, From Https://Databoks.Katadata.Co.Id/Datapublish/2020/08/26/Konsumen-BeralihBerbelanja-Secara-Digital-Saat-Pandemi

Diyatma, A. J. (2017). Pengaruh Promosi Melalui Media Sosial Instagram Terhadap Keputusan Pembelian Produk Saka Bistro. E-Proceeding Of Management, Vol.4, No.1.

Febriani, F. (2017). Pengaruh Strategi Pemasaran Dan Pengembangan Produk Terhadap Minat Beli. Jurnal Ilmu Manajemen, Vol.4, No.2.

Ferdinand, A. (2013). Metode Penelitian Manajemen. Semarang: Badan Penerbit Universitas Dipenogoro.

Ferdinand, A. (2014). Metode Penelitian Manajemen. Semarang: Universitas Dipenogoro. 
Firdaus, A. (2017). Pengaruh Strategi Pemasaran Terhadap Minat Konsumen Membeli Produk Perumahan (Kasus Pada Perumahan Surya Mandiri Teropong Pt. Efa Artha Utama). Jom Fisip, Vol.4, No.1.

Ghozali, I. (2015). Structural Equition Modeling Metode Alternatif Dengan Partial Least Square (Pls). Semarang: Universitas Dipenogoro.

Hasan, A. (2013). Marketing Dan Kasus-Kasus Pilihan. Yogyakarta: Caps.

Herna, Hisnawati, Hidayarturahmi, \& Putri, A. A. (2019). Strategi Komunikasi Media Sosial Untuk Mendorong Partisipasi Khalayak Pada Situs Online Kitabisa.Com. Jurnal Komunikasi Pembangunan, Vol.17, No.2.

Indika, D. R., \& Jovita, C. (2017). Media Sosial Instagram Sebagai Sarana Promosi Untuk Meningkatkan Minat Beli Konsumen. Jurnal Bisnis Terapan, Vol.1, No.1.

Japarianto, E., \& Adelia, S. (2020). Pengaruh Tampilan Web Dan Harga Terhadap Minat Beli Dengan Kepercayaan Sebagai Intervening Variable Pada E-Commerce Shopee. Jurnal Manajemen Pemasaran, Vol.14, No.1.

Kompas.Com. (2020, September 11). Di Tengah Pandemi, Umkm Didorong Inovasi Dan Jualan Secara Online. Retrieved 12 Oktober, 2020, From Https://Money.Kompas.Com/Read/2020/09/11/205212626/DiTengah-Pandemi-Umkm-Didorong-Inovasi-Dan-Jualan-Secara-Online?Page=All

Kompasiana.Com. (2019, Desember 19). Manfaat Instagram Sebagai Media Percepatan Informasi Dan Media Pemasaran. $\quad$ Retrieved Oktober $\quad 11, \quad 2020, \quad$ From Https:/Www.Kompasiana.Com/Hafidfikri/5deddb4ad541df783340ea82/Manfaat-Instagram-SebagaiMedia-Percepatan-Informasi-Dan-Media-Pemasaran

Kotler, P., \& Armstrong, G. (2015). Dasar-Dasar Pemasaran Jilid 1, Alih Bahasa Alexander Sandoro Dan Benyamin Molan. Jakarta: Perhallindo.

Kotler, P., \& Armstrong, G. (2016). Prinsip - Prinsip Pemasaran, Edisi 13, Jilid 1. Jakarta: Erlangga.

Kotler, P., \& Keller, K. L. (2018). Manajemen Pemasaran, Edisi 12 Jilid 1. Jakarta: PT Indeks.

Kwandy, C. P. (2017). Effect Of Brand Image And Price Towards Purchase Intention In Beef-Jerky Company. Review Of Management And Entrepreneurship, Vol.1, No.1.

Laksamana, P. (2018). Impact Of Social Media Marketing On Purchase Intention And Brand Loyalty: Evidence From Indonesia's Banking Industry. International Review Of Management And Marketing, Vol.8, No.1, 13-18.

Lininati, E. (2018). Pengaruh Promosi Melalui Instagram Terhadap Minat Beli Di Food Court. Jurnal Manajemen Bisnis Dan Kewirausahaan, Vol.2, No.2.

Maia, C. R., Lunardi, G. L., \& Dolci, D. (2020). Competitive Price And Trust As Determinants Of Purchase Intention In Social Commerce. Scielo, Vol.16, No.4.

Nisrina, M. (2015). Bisnis Online, Manfaat Media Sosial Dalam Meraup Uang. Yogyakarta: Kobis.

Noor, J. (2016). Metodelogi Penelitian. Jakarta: Kencana Prenada Media Group.

Pakpahan, A. K. (2020). Covid-19 Dan Implikasi Bagi Usaha Mikro, Kecil, Dan Menengah. Jurnal Ilmiah Hubungan Internasional Fakultas Ilmu Sosial Dan Ilmu Politik Universitas Katolik Parahyangan.

Patardo, H. (2020, Maret 27). Trafik Media Sosial Meningkat Selama Masa Pandemi Corona. Retrieved Oktober 11, 2020, From Https:/Www.Tek.Id/Tek/Trafik-Media-Sosial-Meningkat-Selama-MasaPandemi-Corona-B1zju9hu4

Purwarna, D., Rahmi, R., \& Aditya, S. (2017). Pemanfaatan Digital Marketing Bagi Usaha Mikro, Kecil, Dan Menengah (Umkm) Di Kelurahan Malaka Sari, Duren Sawit. Jurnal Pemberdayaan Masyarakat Madani (Jpmm), Vol.1, No.1.

Putri, L. N. (2017). Pelaksanaan Promosi Melalui Media Sosial Instagram Pada Toko Zizara Depok. Jurnal Cakrawala, Vol.17, No.2.

Sciffman, \& Kanuk. (2015). Perilaku Konsumen. Edisi 7. Jakarta: Indeks.

Stanton, W. J. (2016). Prinsip Pemasaran, Edisi Ke Tujuh Jilid 1. Jakarta: Erlangga.

Sugiarto, F. (2016). Analisa Strategi Bersaing Pt. Surya Cipta Mandiri. Agora, Vol.4, No.2.

Sugiyono. (2016). Metodelogi Penelitian Manajemen. Bandung: Alfabeta.

Teo, L. X., Leng, H. K., \& Phua, Y. X. (2019). Marketing On Instagram: Social Influence And Image Quality On Perception Of Quality And Purchase Intention. International Journal Of Sports Marketing And Sponsorship, Vol.20, No.2.

Tjiptono, F. (2015). Strategi Pemasaran, Edisi 4. Yogyakarta: Andi Offset.

Who. (2020). Coronavirus Disease (Covid-19) Pandemic. Retrieved Oktober 6, 2020, From https://www.who.int/emergencies/diseases/novel-coronavirus-2019 